\title{
Primeiro Relato de Plasmopara halstedii em Ageratum houstonianum (Asteraceae) no Distrito Federal, Brasil
}

\author{
Jean Kleber A. Mattos ${ }^{1}$, Bruno Luis A. Pio ${ }^{1}$, Janete Gouveia ${ }^{2}$, \\ Carlos A. Inácio ${ }^{1} \&$ José Carmine Dianese ${ }^{1}$
}

\begin{abstract}
'Departamento de Fitopatologia, Universidade de Brasília, CEP 70910-900, Brasília, DF; ${ }^{2}$ Faculdade da Terra de Brasília/ NOVACAP/Compania Urbanizadora Nova Capital, Departamento de Parques e Jardins, CEP 71215-000, Brasília, DF; e-mail: inacio@unb.br
\end{abstract}

(Aceito para publicação em 06/09/2006)

Autor para correspondência: Carlos A. Inácio

\begin{abstract}
:
First report of Plasmopara halstedii on Ageratum houstonianum (Asteraceae) in Distrito Federal, Brazil

The occurrence of the sunflower mildew caused by Plasmopara halstedii on Ageratum houstonianum (Asteraceae) is reported for the first time in Brasilia, DF, Brazil. The etiological agent was identified according to its morphological characteristics.
\end{abstract}

Plasmopara halstedii (Farl.) Berl. \& De Toni, o agente causal do míldio do girassol e de outras Asteraceae, foi detectado originalmente na América do Norte, porém atualmente está registrado em diversas regiões do mundo. Maisde 100hospedeirassãoconhecidas, incluindo-seespécies silvestres e cultivadas do gênero Helianthus e invasoras dos gêneros Artemisia e Xanthium, todas funcionando como reservatórios de propágulos do fungo (Smith et al., 1992. Data Sheets on Quarantine Pests. Quarantine Pests for Europe. CABI-EPPO). Mais recentemente, P. halstedii foi detectado em Rudbeckia fulgida Ait. Goldsturm no Norte da Flórida (Dankers et al., 2004). No Brasil, Viégas (1945) registrou o fungo em Ageratum conyzoides L. Sieber, em São Paulo. Posteriormente, surgiram relatos em outros estados, inclusive em girassol no Paraná (Yorinori et al., 1983. Resultados de Pesquisa de girassol CNPSo/Embrapa. Londrina p. 34) e em vedélia (Sphagneticola trilobata (L.C. Rich.) Pruski = Wedelia paludosa D.C.) no estado do Ceará (Freire et al., 2003. Fitopatol. Bras. 28:209), no Rio de Janeiro e Minas Gerais (Rocha et al., 2004. Fitopatol. Bras. 29:120). Este é o primeiro relato do fungo no DF, do míldio em Ageratum houstonianum Mill. (Asteraceae), uma espécie ornamental também conhecida por suas propriedades antifúngicas afetando o desenvolvimento de fungos patógenos humanos (Raí et al., 2003. Plant-derived antimycotics: Current Trends and Future prospects, Haworth Press, New York). De novembro de 2004 a maio 2005, plântulas de $A$. houstonianum com sintomas característicos de míldio foram coletadas em Brasília, DF. Os sintomas evoluíam para uma queima foliar. $\mathrm{O}$ material coletado foi primeiro submetido à secagem em estufa por 3-4 dias a $50^{\circ} \mathrm{C}$. As exsicatas foram registradas e depositadas na Coleção Micológica do Herbário UB. A identificação preliminar do fungo foi feita com auxílio de microscópio ótico em lâminas semipermanentes coradas com lacto glicerol/azul de algodão ou
KOH-glicerol/floxina básica. Esporangióforos e esporângios foram medidos e fotografados, permitindo a identificação segura do fungo, a seguir caracterizado. As lesões foliares atingiram aproximadamente $15 \mathrm{~mm}$ de diâmetro, circulares a irregulares, tornando-se coalescentes, marrons, ocasionando queima do limbo foliar, esporangióforo 330-450 × 7-17 $\mu \mathrm{m}$ de diâmetro, hialino emergindo através dos estômatos na face abaxial da folha, ramificado principalmente em ângulos retos, com 2-3 (-4) esterigmas na extremidade da ramificações secundárias e terciárias contendo esporângios; esporângios 14-22 × 12-18 $\mu \mathrm{m}$ diam., hialinos, globóides a elipsóides, lisos, papilados (Figura 1A-F).

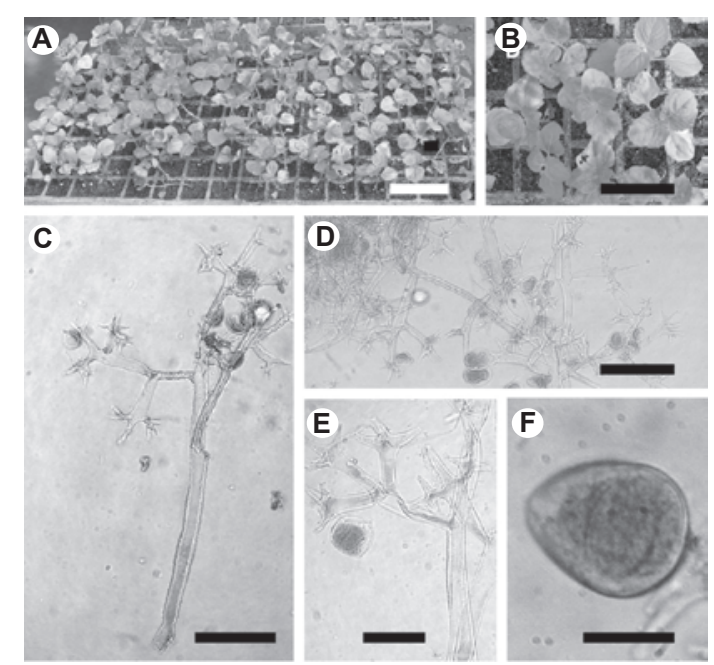

FIG. 1 - Plasmopara halstedii em folhas de Ageratum houstonianum A-B. Sintomas em plântulas; C. Esporangióforos e esporângios (barra $=50 \mu \mathrm{m})$; D. Esporangióforos e esporângios (barra $=50 \mu \mathrm{m})$; E. Esterigmas $($ barra $=50 \mu \mathrm{m}) ; \mathbf{F}$. Detalhe de esporângio (barra= $10 \mu \mathrm{m})$. 